\title{
DOES CATEGORICAL SPECIAL EDUCATION MAKE SENSE? THE FLEMISH SPECIAL EDUCATION SYSTEM IN THE INTERNATIONAL DEBATE
}

\section{Introduction}

In Flanders more than $4 \%$ of the pupils in primary education are going to special schools for mildly mentally handicapped children (M M H-schools, 9.915 pupils, 2.4\%) and to spe cial schools for children with (serious) learning disabilities (LD-school, 8.029 pupils, 1.9\%) (M inistry of the Flemish Community, 1996). The theoretical and practical arguments for the distinction that is made between these two groups of children with learning problems, the nature of which is cognitive (there is, for instance, no sensory or motoric deficiency), are frequently under discussion and have, of course, implications for policy. For reasons of economy investigations are made as to the possibilities of integrating the different types of schools (costcutting through scaling-up) and preventing the growth of special education (costcutting through preventive measures, such as broadening care in regular schools). At the moment the first approach is especially advocated in the $\mathrm{N}$ etherlands. An example of the latter method is found in Flanders as well, inter alia in the strategy that has been developed in the project ' $\mathrm{H}$ elp in learning' by the Federation for Vocational Guidance (C.B.S.O.) and the K.U. Leuven (U niversity of Leuven). For a number of years some forty educational psychologists and special educationists have set up or have given themselves individual remediation in primary schools. O ne of the chief objectives is to advance the quality of diagnosis and to advise in such a way, that when problems arise, the solution is found preferably in the pupil's own school. (Ghesquière et al., 1997a; Ghesquière, et al., 1997b).

In this contribution we will deal with the different arguments and reasons for justification of the existing situation and define our own position. To do so, we will subsequently go deeper into the definition of the problem, discuss various definitions that are the basis of current practice and deal with the problems that are related to categorical special education. After some discussion we will reach a conclusion.

\section{Definition of the problem}

In education, different strategies are being used to help children whose learning process is in danger. First, there are a number of possibilities in the ordinary school. There is the remedial class and the remedial teacher, or the children may not be moved up. N ext, a number of children with learning problems land in extramural services, such as ambulatory rehabilitation centres and the services of licensed speech therapists, remedial teachers, neurolinguists, orthopedagogues or psychologists. Finally, a group of children is referred to special education. Children with learning problems but without a physical handicap or primary behavioural problems are found in type 1 ( $\mathrm{M} \mathrm{M} \mathrm{H}$ ) or in type 8 (LD) schools in Flanders. This structure is found all over the western world (Rispens et al., 1991; V an der Wissel, 1988).

Even though the legislator in Flanders, when classifying special education did not have the intention to discuss types of children, but types of education according to De Fever (1993), the distinction between type 1 and type 8 has to be considered as a classification that is based on child characteristics, mild mental handicap and learning disability respectively. In Anglo-Saxon countries, the classification in "educable mentally retarded" for the one group 
and "learning disabled children" for the other is prevailing (Sutaria, 1987). The learning problems of both groups are referred to, by D umont (1980) among others, as secondary learning problems (mild mental handicap) and primary learning problems (learning disabilities).

H owever widespread this educational and diagnostic differentiation may be, criticism has been voiced for a considerable time by several authors (H art de Ruyter, 1949; 1961; M arston, 1987; Phipps, 1982; Sutaria, 1987; Siegel, 1992) and the question of its use is emerging time and again. For one thing, there is the question of its theoretical relevance and validity, for another, the necessity of categorical education facilities that would answer educational needs appropriate to both groups is doubtful.

\section{Definitions as basis of current practice}

In Flanders, the classification into different types of special education has been regulated by Royal D ecree (R.D.) of 28 June 1978 (Belgian Statute Book of 29 A ugust 1978). A rticle 6, par. 1 stipulates that type 1 , "which is suited to the educational needs of mildly mentally handicapped children and adolescents, is meant for pupils who are not to be considered as educational slow learners and who by means of multidisciplinary examination have been assessed to have a mild developmental delay and/ or mild mental retardation". This definition is clearly aimed at the group of mildly mentally handicapped children. This is emphasised by the exclusion of the so-called 'educational slow learners'. A definition of mild mental handicap, however, is lacking. Furthermore, there is no operationalisation whatever of 'mild' mental handicap and no reference to IQ for instance. All the same, a diagnosis has to be made by an Educational Psychology Service's multi-disciplinary team on the basis of a medical, psychological, pedagogical and social examination (art. $7,1)$, which is expected to follow current views.
The definition of the concept 'mental handicap' by the 'American Association on M ental Retardation' is currently generally accepted and recognised all over the world. It is as follows: "M ental Retardation refers to significantly subaverage general intellectual functioning existing concurrently with deficits in adaptive behaviour and manifested during the developmental period" (Grossman, 1983). Subaverage general intellectual functioning means that on a standardised intelligence test, the person in question scores at least two standard deviations below the average. On most intelligence scales this corresponds to an IQ below 70. People with an IQ between 55 and 70 are considered to be mildly mentally handicapped. 'M ild retardation' roughly corresponds with the educational concept 'educable mental retardation' (Grossman, 1983).

In article 6, par. 8 of the above mentioned R.D. we read that type 8 , "which corresponds to the educational needs of children with serious learning disabilities, is meant for pupils who, although they are normally gifted and their faculties of hearing and seeing are normal, have been assessed by means of a multidisciplinary examination to present disorders of such importance, in language development or in learning to speak and/or write and arithmetic, that special help in regular education is not sufficient". U nlike for the definition of type 1, the law here does give a definition of learning disability, in this case of serious learning disabilities. Several criteria that are being used worldwide (for instance in the DSM-IV of the APA, 1994; D umont, 1990; Lerner, 1997) for the definition of learning disorders are being proposed more or less explicitly. H ere we think of the criteria of normal giftedness, discrepancy and exclusivity. In this there is a large consensus on this domain.

In her discussion of the various definitions of 'specific learning disabilities', Lerner (1997) distinguishes four common elements that are of interest in this context. The first concerns specificity of the problem. It pertains to 
problems in language development and/or the acquisition of academic skills such as reading, spelling and arithmetic. Secondly, she points out the disharmonic development of the diverse components of general intelligence. This aspect is often used to differentiate learning disabled from mildly mentally handicapped children. In this connection Vlietstra's metaphor of the chandelier is striking: when all the lamps of the chandelier are dimmed, we have a mildly mental handicapped, but if some are turned off and the rest are shining normally, then we have a learning disabled child (cited in van der Wissel, 1978). A third common element in most definitions of learning disabilities is the criterion of discrepancy. Learning disabled children are characterised by an unexpectedly big difference between their potential and their actual achievement in school. Finally, there is the criterion of exclusivity. The surprisingly low performance does not result from another handicap or environmental (educational or socio-economic) influences. Q uite a number of authors associate it with the criterion of normality. Learning disabled children are expected not to be mentally handicapped and to have a normal, average general intelligence. Dumont (1990) operationalises this as an IQ equal to or above 85 . Incidentally, this calls into being an intermediate group, with an IQ between 70 and 85 , which is not covered by the definitions above.

When based on the above definitions, there do not sem to be any problems at first sight, neither in regard to the diagnostic classification, nor with respect to educational differentiation. Simply on the basis of intelligence test scores both groups can be subdivided exactly in a group with an IQ below 70 and one with an IQ equal to or above 85. Thus the definition of the target groups of various types of special education apparently leaves no room for obscurity. As we have suggested before, how ever, (and the intermediate group certainly plays a part) it turns out that this is not the case. In the practice of Educational Psychology Services this differentiation proves to be a constant problem (Swinnen, 1986)

\section{Problems related to categorical special education}

\section{Educational differentiation?}

An important part of the difficulties in educational differentiation (see "D efinition of Problem") is a consequence of the strict division of the above target groups, resulting in a group of children with serious learning problems which is situated between both diagnostic categories and which has an IQ between 70 and 85 (Ames, 1977). In practice, one is forced to seek a solution for these pupils in special education when regular education does not offer any possibilities. It is the multidisciplinary team that decides whether type 1 or type 8 is advisable for a specific pupil. Several factors, for example the availability of such schools in the region, may play a role. In this connection, however, there is criticism that the decision is made based especially on information concerning the family's socio-economic environment. Van Gennep (1977), for example, proving that social status is of greater differentiating significance in regard to special education than academic achievement and IQ, declares, "It would be cynical to use socio-economic data as a criterion for selecting a school for the mentally deficient, but this would not be more cynical than reality itself." (p. 80-81). The same criticism is found in Ames (1977), who states that special education for children with learning disabilities in the $U$ nited States came about only because for some parents the word 'mentally handicapped' was too emotionally loaded. Van der Leij and Kool (1981a) are also convinced of this. "For children who meet the norms as regards social background, but not as regards academic progress, a separate school has been created (LD-school), although learning problems in both categories can show strong resemblances." (p. 162). 
Once again, we should realise that these problems are the result not so much of a theoretical obscurity in defining the concepts of mild mental handicap and specific learning disability, but especially of the practice of looking for and referring to adequate care outside regular primary education. Even when surmising that the learning problems of mildly mentally handicapped children are different from those of children with learning disabilities, we realise that the intermediate group and the multidisciplinary team's choices (using restricted instruments) cause an overlap between both types of education that is not to be ignored. This may carry the risk that in practice there is no clear educational differentiation. A ccording to Van der Leij and Kool (1981a) this is the case. After interviewing 50 teachers from LD and $\mathrm{MMH}$-schools, it turned out that the differences between the methods used in schools of one and the same type were as great as those between schools of a different type. H owever, they indicate that the pace in an $\mathrm{M} \mathrm{M} \mathrm{H}$-school is reduced and that they use more material.

In the Discussion section we will come back to the fact that these qualitative aspects may be of importance for a necessary educational differentiation. Van der Leij and Kool's criticism of educational differentiation, however, goes deeper. On the basis of data from two regions they declare that both types are comparable as regards their referral to further education. (For Flanders we have no data on this matter.) From their point of view not only the teaching method is the same, but the result as well. What is more, they consider the fact that in an integration-experiment with $\mathrm{LD}$ and $\mathrm{MMH}$ schools, pupils from both groups showed equal progress - be it on a different level - to be another confirmation of their proposition ( $V$ an der Leij and Kool, 1981b; Van der Leij et al., 1984). $M$ arston (1987), on the basis of research into the effect of separate teacher training for both types of education, reaches the same conclusion. $\mathrm{N}$ o difference in progress is noticeable between mildly mentally handicapped and learning disabled children, no matter which teacher is instructing them.

Fundamental is the question whether it is advisable at all to develop an educational system based on diagnostic classifications of individual pupils. Goldstein et al. (1975) give a summary of the advantages and disadvantages. We take those which are relevant to our discussion and should be taken into account in special education. The advantages are:

1. The possibility of clear communication be tween different experts involved in the educational system.

2. A simpler and more translucent administration and subsidy scheme. In the U nited States there is criticism that this might be the most important reason for excluding the mentally handicapped from education for the learning disabled (Sutaria, 1987).

3. Continuous community support of special education is guaranteed. I dentifying clearly defined groups motivates more than do vague educational objectives.

\section{D isadvantages include:}

1. Classification is conducive to generalisations concerning individual pupils and obscures individual differences between children in the same category.

2. Descriptive categories often operate as explanatory categories, which may lead to circular arguments.

3. An educational system of this kind overlooks the interactive character of teaching and confirms the erroneous assumption that a learning disability is found exclusively in the child.

4. Descriptive categories often provide information that is irrelevant from an educational point of view but leads the teacher's expectations in a certain direction, the re sult being a self-fulfilling prophecy. 
5. There is no immediate and clear connection between diagnostic classification and the corresponding educational needs.

\section{Diagnostic differentiation?}

Criticism of diagnostic differentiation be tween mildly mentally handicapped children and children with a learning disability can be especially traced back to scepticism about the difference between primary and secondary learning disabilities. M ore specifically, a number of authors doubt the chief constitutive elements in the definition of 'specific learning disabilities', that is, the criterion of specificity, the disharmonious profile, the criterion of discrepancy and the criterion of exclusivity (see "D efinitions as basis of current practice"). We will briefly deal with the major objections.

Especially the criterion of discrepancy comes under fire. The first aspect that comes to the fore in this discussion is the fact that there is no necessity for this criterion to discriminate between the two groups. The discrepancy between learning potential and actual learning achievement is in itself independent of the level of intelligence (Sutaria, 1987). It is true that the statistical norm aimed at is very difficult to attain for children who score poorly on intelligence tests. In addition, the criterion of discrepancy does not allow the early detection of serious problems. The pupil would already be far behind before there could be any talk of a learning disability. Prevention, therefore, be comes problematic ( $V$ an der Leij and Kool, 1981a).

O ne of the major points of criticism is directed at the use of intelligence tests as a measure of learning potential. There are two main arguments. First, it turns out that with normally gifted pupils there is but a relatively limited correlation between intelligence and school progress, from .20 to .60 , subject to age (Swinnen, 1986). This correlation may even decrease when the pupils are less skilled ( $V$ an der Leij and Kool, 1981a), although it is obvious that, when endowment is substandard, the correlation will increase. The second argument is that IQ is a static measure and in itself does not say a lot about learning as such. The dynamic learning process cannot be expressed in IQ. M oenaert (1991) shows that various alternatives have already been given, including learning potential tests (for a review see $H$ amers et al., 1993). Yet he regards the success of these attempts as uncertain. $\mathrm{N}$ ot to be identified with the criticism of the use of IQ as a measure of learning potential is the criticism of the statistical techniques used to assess discrepancy (Swinnen, 1986; M oenaert, 1991; Evans, 1992; Stelwagen, 1993). In a nutshell, it comes down to discrepancy formula making severe psychometric demands on the instruments used and on the knowledge of the relationship between the different scores and the target groups for which they are used. There are no empirical data on the relationship between the different scores. A part from that, discrepancy in practice is often measured independently of intelligence, that is, by comparing an individual pupil's learning achievement to that of his peers (Rispens, 1989). This method, however, does not take into account the individual possibilities of the pupil in question (M oenaert, 1991).

The criterion of the disharmonic development of the diverse components of general intelligence is under discussion as well. Rispens (1989) gives a review of research on the use of profile analysis when diagnosing dyslexia. This leads to the conclusion that there is hardly any basis for expecting to obtain reliable and valid information this way. Answering differentialdiagnostic questions based on profile analysis does not seem to be justified. M oenaert (1991) also gives a similar critical analysis of this aspect. Van der Leij and Kool (1981a) report data proving that in practice the intelligence profiles of children from M M H-schools and children from LD-schools are very similar. On this basis they have modified the above chandelier metaphor. "At the most one can refer to a chandelier 
that in general shines faintly and a chandelier that gives more light; the bulbs that are relatively weaker or stronger are nonetheless situated in the same places." (Van der Leil and Kool, 1981a, p. 160). Their conclusion is that this criterion as well does not provide sufficient differentiation between both groups.

As to the criterion of specificity, the situation is as follows. When related to problems with the academic skills of reading, spelling and arithmetic, this criterion does not differentiate between children from $\mathrm{M} \mathrm{M} \mathrm{H}$ and those from LD -schools (V an der Leij and Kool, 1981a). In relation to learning disability, specificity, however, is often used in yet another meaning: that of a partial defect. This reveals itself especially in discussions on the definition of dyslexia (Van den Bos, 1991). In this context M oenaert (1991) refers to discrepancies within academic skills. $0 \mathrm{n}$ the basis of a review of research into this matter he concludes, "Significant intra-individual differences as to the subjects of Ianguage and arithmetic. Although inherent in the definition of specific learning disability, are mostly believed without sound empirical control. When there was a check all the same, it was impossible to differentiate on the basis of academic discrepancies." (p. 53). A confirmation of this thesis can be found in research carried out by Siegel (1992). "These two groups did not differ in their performance on reading, spelling, phonological processing, or most of the language and memory tasks." (p. 618). This finding is in harmony with teachers' experiences in special education. Van Rijswijk and Zijlmans' research (1988) proves that, whereas formerly the LD-school had to face problems more often in one subject, today one is confronted with important delays in all subjects. Consequently, this criterion too would not provide sufficient differentiation between the target groups of both educational types.

As to the criterion of exclusivity, it is clear that in both groups there is no question of sensory or physical handicaps being the cause. The exclusion of limited environmental conditions, however, is much more delicate. In this connection we refer to the discussion on socio-economic differences between the two types. Categorisation according to Van der Leij and Kool (1981a) has a discriminating effect. Excluding a mental handicap when defining a primary learning disability is under discussion on the basis of all arguments cited. In the opinion of a number of authors, no valid distinction can be made between the learning problems of mildly mentally handicapped children and those of normally gifted children (Sutaria, 1987).

But the criticism of the distinction between primary and secondary learning problems is not the only source of scepticism about the diagnostic differentiation between mildly mentally handicapped children and those with learning disabilities. There is also the fact that both groups have a lot of behavioural characteristics in common (Sutaria, 1987). In an exploratory research project in Flanders on behavioural and emotional problems with children who have learning problems (G hesquière et al, 1997c) the parents declare that they are afflicted largely by problems of a social nature (behaving too young and too independently, being bullied, not being popular ...) and of attention (unable to concentrate, to be quiet, be ing impulsive ...). These problems correspond significantly with the personality of the mildly mentally handicapped youngster and, precisely because of this interrelation, a lot of authors are doubtful about the distinction between both groups (Sutaria, 1987).

\section{Discussion on the problems that have been reported}

\section{Educational differentiation after all?}

In this contribution we deal especially with categorical special education. It is, however, worthwhile to distinguish that from regular primary education. LD-schools in principle have the same learning goals as regular 
primary education, whereas this is not the case with $\mathrm{MMH}$-schools. Integrating both types would therefore be less obvious than integrating LD -schools and regular primary education. In practice, however, M M H, LD and regular primary education can be regarded as three moments on a floating scale with respect to the pupils' intellectual potential (e.g. Resing and Bleichrodt, 1989; Resing, 1990) as well as academic achievement. The idea that, with regard to intellectual abilities, particularly pupils from LD -schools resemble those in regular primary education, has not been proven in practice. In other words, a discussion on the possibility of integrating $\mathrm{M} \mathrm{M} \mathrm{H}$ and LD-schools in principle is striking because of the differences in the objectives they strive for, but obviously realistic in view of what takes place in practice. Even then the question is justified whether it would not be wiser to have a look at the original intention of LD -schools, instead of upgrading practice's imperfections to a principle. If poor practice is used as a standard, it will make no difference to the government whether $\mathrm{M} \mathrm{M} \mathrm{H}$ and LD-schools are integrated or $M M H, L D$, and regular primary schools. Differences between children in that case are nothing more than a question of level and the solution as simple as irrealistic: the teacher 'only' has to differentiate.

Increase in scale and expansion of care are two different points of view when discussing integration (see 'Introduction'). Both are measures on a macro level, even when the impact of expansion of care is unmistakably on a meso level. Educational differentiation within school will always be part of answering differences in the pupils' need of instruction. In the section "E ducational differentiation" we have shown that advocates of an increase in scale are putting forward mainly two arguments: that both types of special education use the same methods and have the same results. This however calls for some reflection.

The first consideration concerns the socalled equal teaching effect. Research referred to reveals that in integration projects pupils from
M M H and LD-schools progress at the same rate in learning. There is still a difference in level, but progress is comparable. H owever, this difference in level is beginning to appear and this apparently implies that both groups are at least showing a tendency to grow apart. In 'H ulp op maat' (Custom made care) (Dienst Onderwijs, Rotterdam, 1993) for instance (a project analysing profiles of care of LD and $\mathrm{M} \mathrm{M} \mathrm{H}$-schools in Rotterdam - the $\mathrm{N}$ etherlands, 1990-1993) learning efficiency in special education is reported. Learning efficiency in reading, spelling and arithmetic in $\mathrm{M} \mathrm{M} \mathrm{H}$-education per year is 6, 5 and 5 months respectively. For LD education this is 7, 9 and 8 months. Children in $\mathrm{M} \mathrm{MH}$-schools on an average progress almost half a year per year; for LD-schools pupils this is 8 months. A similar learning progress in integration research is only possible when investments in one group are greater than in the other. A closer analysis of research shows that comparable learning progress occurs only when in the research's design, differentiation in the quality of instruction has been provided for and when no 'normal' level has been preset as an objective. Van der Leij and Kool (1981a) rightly point out the differences in learning pace and in the need for concrete material.

Furthermore, in this connection it is necessary to point out the variation research has found in the extent to which both groups are capable of generalising what has been learned. As to arithmetic, V an Luit (1987, p. 164) concludes: "A pplicable to the education of pupils with arithmetic disabilities in $\mathrm{M} \mathrm{M} \mathrm{H}$-schools is the fact that, apart from exceptions, each new step that has to be taken in the sequence of tasks has to be instructed. M ildly mentally handicapped children are incapable of discovery learning, even after a training that has produced learning progress. In other words, even after specific training $\mathrm{M} \mathrm{M} \mathrm{H}$-pupils are not able to solve arithmetic problems if they have not been taught to do so." Such divergence in the extent to which that which has been learned can be generalised, has also been reported by 
Ruijssenaars and $\mathrm{H}$ amers (1989). M M H -pupils show that they need instruction more fre quently and basically of another type at each new step taken in the learning process and this instruction alone is by far not always transferable to the next parallel task.

In short, even if with different expediences in instruction both types of pupils can accomplish a learning progress, achievement will gradually diverge, because one group simply transfers what it has learned to other learning situations and by doing so increases its advantages.

The phenomenon above has to do with differences that are situated on the level of pupil characteristics, the micro-level. In our opinion, learning problems should be reported not primarily in terms of how far a pupil is behind his/ her peers in the level of performance or of the level of achievement only (for instance the progress made in a specified period of time), but especially in terms that characterise learning as a process, e.g. the components of the learning process where there is a failure; proficiency in making use of instruction; the extent to which that which has been learned is transferred. Differences between pupils with learning problems consist not only in differences in success or level, but certainly also in a need for different instruction. 0 ne possibility is to make useful strategies more or less explicit, to call more or less on the pupils' ability to verbalise as a means of directing the thinking process, to let the pupil himself search actively for moments where what has been learned can be used, and to help the pupil in handling strategies of planning and control. In the project ' $\mathrm{H}$ elp in Learning' we presented in the Introduction, we attempt to bring remediation and the individual need for instruction into harmony, making use of a number of clearly defined principles (see Ruijssenaars et al., 1992; 1993). In practice there may be a consensus as to the methods to be used. This, however, is in sharp contrast to the differences in instructional need that have been observed empirically.

\section{Diagnostic differentiation after all?}

W e have seen that the criteria for differentiating pupils for M M H and LD-schools in Flanders as such are clear (see D efinition of the problem), but that in practice a problem arises because of the so-called intermediate group. This problem is even intensified because the instrument, the usual intelligence test, does not sufficiently differentiate between children whose learning potential is higher and those whose learning potential is lower. N otwithstanding M oenaert's (1991) doubts in this matter, we are convinced that the learning test does offer a solution (see $\mathrm{H}$ amers et al., 1993). Resing (1990) in her research compared learning potential scores (learning tests) with standard intelligence scores and concludes, " $\mathrm{O} n$ the basis of learning potential scores and academic achieve ment not less than $37.5 \%$ of the LD-pupils would be ranked as $\mathrm{MMH}$-pupils and $5 \%$ as primary school pupils. However, on the basis of standard intelligence scores and academic achievement $17.5 \%$ of the LD -pupils would be regarded as $\mathrm{M} \mathrm{MH}$ and $7.5 \%$ as primary school pupils. For M M H pupils these differences are less explicit; on the basis of learning potential scores and academic achievement $16.2 \%$ would be classified as LD pupils, on the basis of standard IQ scores and academic achievement $24.3 \%$ of these pupils would be classified as LD pupils" (p. 184-185). In short, whereas the criteria are clear in principle; differentiation in practice is a problem, because an intermediate group of pupils is also referred to one of both types - using tools that give only limited backing for such a decision.

\section{Conclusion}

In "D efinition of the problem" we have questioned the theoretical relevance and tenability of the classification in primary and secondary learning problems as well as the need for several educational facilities that would fit this 
classification. In our opinion, a theoretical differentiation is defensible when typical differences in the learning process and in the need for instruction are taken into account. In principle, this already answers the question whether diversity in the instruction that is offered is sensible. The combination of this question with the one asking for the best form of organisation, leads to problems, because the criteria for a correct classification in practice turn out to be understood in a very wide sense, whereas the means that are used for its operationalisation are but partially suited to their aim. We, however, believe that it would be unjustifiable to play down and simplify the differences in pupils' instructional need to just differences in learning levels because of inadequacies in practice. In "Educational differentiation" we have reported some disadvantages, borrowed from Goldstein et al. (1975), which are related to the use of diagnostic classification in order to refer individual pupils to different types of education. We can subscribe to these disadvantages insofar as they are to be understood as dangers, but here too applies that one should not throw away the child (the best possible individual approach) with the bathwater (bad practice).

\section{Summary}

In Flanders, special education for children with cognitive learning problems, that is, for the mildly mentally handicapped and for the learning disabled, is organised in a categorical (based on diagnostic categories) education system. This structure, which is found all over the Western world, is frequently under discussion. This contribution deals with the different arguments as well as the reasons for justification and criticism of the situation as it is now. On the basis of the international debate concerning categorical education for these children, we present a new perspective for the Flemish special education system.

\author{
*Prof. Dr. Pol G hesquière \\ Professor of Special Education, \\ University of Leuven, \\ Faculty of Psychology and Educational Sciences, \\ Department of Special Education, \\ Vesaliusstraat 2, B-3000 Leuven, Belgium \\ Tel: ++32163262 34 \\ Fax: ++3216325933 \\ pol.ghesquiere@ped.kuleuven.ac.be
}

Prof. Dr. A. J. J. M. Ruijssenaars

Professor of Special Education,

University of Leiden, The Netherlands

* For Correspondence

\section{References}

Ames, L. B. (1977). Learning Disabilities: Time to Check Our Roadmaps? Lournal of Learning Disabilities, 10, 328-330.

American Psychiatric Association. (1994). Diagnostic and Statistical $M$ anual of $M$ ental Disorders. Fourth Edition. DSM -IV. Washington DC.: A.P.A.

De Fever, F. (1993). Het buitengewoon onderwijs. In: E. Broekaert, F. De Fever and W. Hellinckx (Eds.). Orthopedagogische werkvelden in kaart: Vlaanderen. KOP-serie 5, (pp. 59-114). Leuven/Apeldoorn: Garant.

Dienst Onderwijs Rotterdam (1993). Hulp op maat. A nalyse van zorgprofielen van LOM en M LK scholen. Rotterdam: Dienst Onderwijs, Postbus 70014, 3000 KS.

Dumont, J. J. (1980). Leerstoornissen. Deel 1: Theorie en model. Rotterdam: Lemniscaat.

D umont, J. J. (1990). D yslexie: Theorie, diagnostiek, behandeling. Rotterdam: Lemniscaat.

Evans, L. D. (1992). Severe Does Not Always Imply Significant: Bias of a Regression Discrepancy Model. Lournal of Special Education, 26, 57-67.

G hesquière, P., G rietens, $\mathbf{H}$. and Ruijssenaars, A. J. J. M. (1997a). Effectiveness of Individual task-oriented remedial teaching for children with arithmetic problems. Symposium presentation at the 7th EARLI-conference, Athens, Greece, August 26-30, 1997.

Ghesquière, P., Luyckx, E., Grietens, H. and 
Ruijssenaars, A. J. J. M. (1997b). Prevalence and treatment of word recognition problems in 3rd and 4th graders from primary schools in Flanders. Paper presented at the 4th International Conference of the British Dyslexia Association, in co-operation with the European Dyslexia Association, 'Dyslexia: Biological Bases, Identification and Intervention', The University of York, April 1st-4th, 1997.

G hesquière, $P_{\text {., }}$ G rietens, H . and H ellinckx, W. (1997c). Prevalence of problem behaviour in a general sample of learning disabled children. International Journal of Child and Family W elfare. (Submitted for publication).

G oldstein, H., A rkell, C., A shcroft, S. C., H urley, O. L. and Lilly, M. S. (1975). Schools. In: N. Hobbs (Ed.) Issues in the Classification of Children. Volume Two: A Sourcebook on Categories, Labels, and Their Consequences. (pp. 4-61). San Francisco: Jossey-Bass.

G rossman, H. J. (1983). Classification in M ental Retardation. Washington D.C.: American Association on Mental Deficiency.

H amers, J. H. M., Sijtsma, K. and Ruijssenaars, A. J. J. M. (1993). Learning Potential A ssessment. Theoretical, M ethodological and Practical Issues. Lisse/Amsterdam: Swets \& Zeitlinger.

Hart de Ruyter, T. (1949). O ver de differentiatie tussen debilitas mentis en zwakbegaafdheid. Den Haag: Haga.

Hart de Ruyter, T. (1961). Debilitas mentis, zwakbegaafdheid en vertraagde ontwikkeling. (Orthopedagogische geschriften) Groningen: Wolters-N oordhoff.

Lerner, J. W. (1997). Learning D isabilities: Theories, Diagnosis, and Teaching Strategies (7th Edition). Boston: Houghton Mifflin Company.

M arston, D. (1987). Does Categorical Teacher Certification Benefit the Mildly Handicapped Child? Exceptional Children, 53, 423431.

Ministerie van de Vlaamse Gemeenschap. (1996). Statinfo B.S.T.: Beperkte statistische telling van de leerlingen- en studentenaantallen in september-oktober 1996. Brussel: Departement Onderwijs, Bestuur Statistiek.

Moenaert, H. (1991). Intelligentie en schoolse problemen: een onderzoek bij zeven- tot tienjarigen (doctoraatsproefschrift). Leuven:
K.U. Leuven, Faculteit Psychologie en Pedagogische Wetenschappen, Afdeling Psychodiagnostiek en Psychologische Begeleiding.

Phipps, P. M. (1982). The Merging Categories: Appropriate Education or Administrative Convenience? Lournal of Learning D isabilities, $15,153-154$.

Resing, W. C. M. (1990). Intelligentie en leerpotentieel. Een onderzoek naar het leerpotentied van jonge leerlingen uit het basisen speciaal onderwijs (doctoraatsproefschrift). Amsterdam/Lisse: Swets \& Zeitlinger.

Resing, W. C. M. and Bleichrodt, N. (1989). Intelligentiemeting bij kinderen uit het speciaal onderwijs: de betekenis van de RAKIT voor L.O.M.- en M.L.K.-leerlingen. $\mathrm{N}$ ederlands Tijdschrift voor de Psychologie, 44 382-389.

Rispens, J. (1989). De rol van het intelligentieonderzoek in de diagnostiek van kinderen met dyslexie. In: A. J. J. M. Ruijssenaars and J. H. M. Hamers (Eds.). Dyslexie: Ernstige lees- en spellingproblemen. Een overzicht van theorie en praktijk. (pp. 25-34). Leuven/ Amersfoort: Acco.

Rispens, J., M eijer, C. J. W. and Pijl, S. J. (1991) Over de grens van regulier en speciaal onderwijs. Een vergelijkend onderzoek naar de organisatie van het speciaal onderwijs in een zevental landen. Tijdschrift voor O rthopedagogiek, 30, 93-106.

Ruijssenaars, A. J. J. M. and H amers, J. H. M. (1989). Instructiegerichte diagnostiek. Pedagogische Studiën, 66, 12-22.

Ruijssenaars, A. J. J. M., Roesems, G ., Van den Brande, H. and Vercammen, E. (1992). Project leerhulp: ervaringen en inzichten. 19911992. Leuven: K.U. Leuven, Afdeling orthopedagogiek, i.s.m. begeleidingsdienst Vrije PMS - centra.

Ruijssenaars, A. J. J. M., Roesems, G., Van den Brande, H. and Vercammen, E. (1993). Project leerhulp: ervaringen en inzichten. 19921993. Leuven: K.U. Leuven, Afdeling orthopedagogiek, i.s.m. begeleidingsdienst Vrije PMS - centra.

Siegel, L. (1992). An evaluation of the discrepancy definition of dyslexia. Lournal of Learning D isabilities, 25, 618-629. 
Stelwagen, F. J. (1993). Een receptuur voor de behandeling van dyslexie. In: A. J. J. M. Ruijssenaars and J. H. M. Hamers (Eds.). Leerproblemen op school. Lees- en spellingproblemen: Praktijk en onderzoek. ( $p p$. 35-71). Leuven/Amersfoort: Acco.

Sutaria, S. (1987). M ental Retardation and Learning Disabilities: A Categorical Issue: Literature Review. Presented at the 7th World Congress of the International Association for the Scientific Study of Mental Deficiency, New Delhi, India, March 1985.

Swinnen, K. (1986). Gevaren verbonden aan het gebruik van intelligentiescores in de differentiële diagnostiek van kinderen en jongeren met leerproblemen. In: P. J. Janssen, G., Van der Steene and $\mathrm{H}$. Vertommen (Eds.). Intelligentie: Tussen meten en weten in theorie en praktijk. Festschrift voor Prof. D r. J. Stinissen. Studia Psychologica (pp. 169-202). Leuven: Universitaire Pers.

Van den Bos, K. P. (1991). De definiëring van dyslexie volgens een eenvoudig leesmodel. In: K. P. Van den Bos and H. Nakken (Eds.). Dyslexie '91. Verslag van een studiedag gehouden aan de Rijksuniversiteit Groningen op 29 mei 1991. (pp. 23-41). Amsterdam/Lisse: Swets \& Zeitlinger.

Van der Leij, A. and Kool, E. (1981a). LOM/ MLK. Deel 1: Kritische kanttekeningen bij de diagnostische en onderwijskundige differentiatie. Tijdschrift voor 0 rthopedagogiek, 20, 153-168.

Van der Leij, A. and Kool, E. (1981b). LOM/ MLK. Deel 2: Enkele voorlopige konklusies over de mogelijkheden tot onderwijskundige integratie. Tijdschrift voor Orthopedagogiek, 20, 199-222.

Van der Leij, A., Kool, E. and Wielenga, A. (1984). Vernieuwing van speciaal onderwijs. Een voorbeeld van LOM/MLK-integratie in theorie en praktijk. Orthovisies 20. Groningen: Wolters- Noordhoff.

Van der Wissel, A. (1978). Percepties van verschillen tussen LOM- en ML-leerlingen. Interviews met naast-betrokkenen. Tijdschrift voor O rthopedagogiek, 17, 299-324.

Van der Wissel, A. (1988). De lom/mlkdifferentiatie in de visie van de Russische defectologen. Een tweetal kritische vragen. Tijdschrift voor Orthopedagogiek, 27, 444-448.
Van Gennep, A. (1977). D ebiliteit en maatschappelijke ongelijkheid. De mythe van het moeilijk lerende kind. Amsterdam: Boom Meppel.

Van Luit, J. E. H. (1987). Rekenproblemen in het speciaal onderwijs. Een onderzoek naar de invloed van de methode van zelfinstructie en een specifiek rekenhulpprogramma op de rekenvaardigheid. (academisch proefscrift) Nijmegen: Instituut voor Orthopedagogiek.

Van Rijswijk, C. M. and Zijlmans, S. W. M. (1988). Gepercipieerde veranderingen in kenmerken van lom-leerlingen. In: K. Doornbos, C. M. Van Rijswijk and A. F. D. Van Veen, Verschuivingen in orthopedagogische werkvelden. Publikaties van het Amsterdams Pedologisch Centrum 4. Amsterdam/Lisse: Swets \& Zeitlinger. 